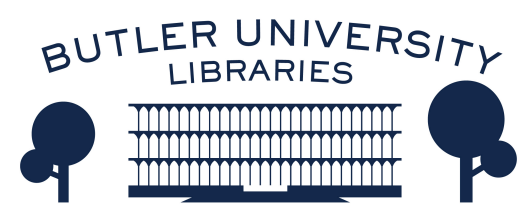

Journal of Hindu-Christian Studies

Volume 11

Article 8

January 1998

\title{
The Hindu Presence in Europe and Implications of Interfaith Dialogue
}

Martin B. Baumann

Follow this and additional works at: https://digitalcommons.butler.edu/jhcs

Part of the Religion Commons

\section{Recommended Citation}

Baumann, Martin B. (1998) "The Hindu Presence in Europe and Implications of Interfaith Dialogue," Journal of Hindu-Christian Studies: Vol. 11, Article 8.

Available at: https://doi.org/10.7825/2164-6279.1181

The Journal of Hindu-Christian Studies is a publication of the Society for Hindu-Christian Studies. The digital version is made available by Digital Commons @ Butler University. For questions about the Journal or the Society, please contact cbauman@butler.edu. For more information about Digital Commons @ Butler University, please contact digitalscholarship@butler.edu. 


\title{
The Hindu Presence in Europe and Implications of Interfaith Dialogue
}

\author{
Martin B. Baumann \\ University of Hannover
}

\section{Christian Dominance in Europe}

The World's Parliament of Religions held in Chicago in 1893 is often referred to as the catalytic start of organized interfaith activities in Canada and the United States. Europe, however, cannot look back to such a pioneering event. One may point to the Religions of the Empire Conference, held in 1924 in conjunction with the British Empire Exhibition in London, or the World Congress of Faiths in 1936. These incipient initiatives of an interfaith dialogue were confined to Great Britain only and did not reach the continent.

Interreligious activities as the encounter between representatives of different religious traditions and interfaith meetings as an expression of an increasing reflection on the relation and mutual impact of living side by side in an rapidly expanding multi-faith society did not begin in any significant way in European countries before the 1970s. It may be argued that the demand to consider how to treat non-Christian religions in a non-patronizing and non-hegemonic way occurred out of a defensive, reactive manner. The sheer fact that from the 1950 s and 1960s immigration did not only bring workers and people to Great Britain, France, Germany, and other European countries, but also non-Christian customs and faiths urged Christian spokesmen to cope with the new situation. It must be stated that in most European countries Christian churches still play a socio-political leading role, more often than not supported by special legislation. Thus it is not primarily certain challenging doctrinal concepts (or whatever), but the numerical size and societal impact of the new non-Christian community in each respective country that appears to be the decisive reason of stirring up requirements to reflect upon interfaith relations. Interreligious dialogue with Muslims has become a primary issue in most European countries, due to the comparatively large numbers of North African, Turkish, and South Asian Muslims in France $(3,000,000$ or $5 \%$ of the population), Germany $(2,500,000$ or $3 \%)$, Britain $(1,500,000$ or $2,6 \%)$, and the Netherlands $(500,000$ or $3 \%)$. Dialogue with the Jewish traditions also has a prominent place within the field of interfaith activities, due both to the centuries-long history of Jews in Europe and the holocaust in Germany under the Nazi regime.

Compared to Muslim-Christian and Jewish-Christian dialogue, interfaith activities as regards the Hindu presence in Europe are comparatively few and of an incipient nature. In the next section I outline, on the one hand, this low-key concern, which is due to the short history of Hindu communities in various European countries. On the other hand, up to now the Hindu presence has not stirred up any major societal problems or implications felt to be threatening to dominant socio-cultural and religious norms. Then I sketch a few examples of such joint activities and will point to representational implications of these interfaith meetings. The last part will argue that the offer and invitation to become involved in a multi-faith dialogue has had a far greater impact on the reconceptualization of Hindu traditions than it has had for the 
Christian partners. Living in a diasporic situation, faced by both a secular environment and other, non-Hindu faiths, has given rise to structural, i.e. Christian alignments, sometimes sought after, sometimes unavoidable.

\section{The Diversity of Hindu Diasporas in Europe \\ The so-called "Hindu Diaspora in Europe"} consists of a multitude of separate diasporas. Gujarati, Punjabi, Indo-Caribbean, Surinamese, and Sri Lankan Hindus have created their own homes away from home, bringing with them a diversity of ethnic styles and cultural patterns. Kinship, caste, region of origin, and affiliation to a religious subtradition (sampradaya) differentiate the about 700,000 or more Hindus living in Europe at the end of the millennium.

The current presence of Hindu traditions in Europe is the result of several waves of numerically strong immigrations. Although in Great Britain individual Zoroastrians, Muslims, and Hindus have lived since the 19th century, the number did not rise until the massive immigrations during the 1950s and 1960s. Large numbers of South Asians and West Indians came to Britain in order to fill the labour shortage in British post-war industry. In contrast to Muslims and Sikhs, Hindus were the last to open proper places for worship, the first being a temple in Coventry in 1967, followed by a temple in Leicester in 1969. The establishment of temples was due, on the one hand, to the arrival of Hindu women and children in the course of family reunion during the 1960 s. The former all-male households changed to family and kinship households. The sojourners became settlers and the "myth of return" declined. This process was accompanied by the flight of East African Asians to Britain in the wake of the Africanization policies. These African Indians came to Britain in complete family units and their previous experiences of establishing social and religious institutions was quickly employed to re-establish relevant institutions in Britain. ${ }^{1}$

Since the end of mass immigration in 1973 , the proliferation of religious organizations and activities has continued. Furthermore, the emergence of the second generation led to mother-tongue classes, to youth groups, and to adaptation to the British life-style. Calculations estimated the existence of 100 Hindu temples in 1982, growing to more than 300 in the early 90 s. The temples and places of worship have been established in adapted private houses, previous schools, community centres, or in converted churches. In Coventry, Leicester, and London purpose-built temples have existed since the early 1990s. It is in these regions, Greater London and the conurbations of the Midlands, that the majority of Hindus live. By the mid-1970s, some 300,000 Hindus had settled in Britain. The estimated figure for the mid-1990s ranges from some 400,000 to 550,000 Hindus. ${ }^{2}$

The vast majority of Hindus living in Britain came from the Punjab and Gujarat, either directly or via East Africa. Gujaratis make up about $70 \%$ of the Hindu population. Far from being a homogenous ethnic group, the Gujarati population in Britain similar to Gujarat itself - is excessively subdivided according to origin from local Gujarat region, caste, and sampradaya. Britain's most prominent and energetic Gujarati sampradaya is the "Hindu Swaminarayan Mission", inaugurating Europe's first traditionally styled Hindu mandir (temple) in Neasden (London) in 1995. Furthermore, in addition to Hindus from the Punjab (15\%) and other Indian states, from 1983 onwards an increasing number of Tamil refugees from Sri Lanka applied (mostly in vain) for asylum. Finally, and often forgotten, some 30,000 Hindus from Trinidad and Guyana have settled in Britain.

In addition to these Hindus of Indian origins, "Hindu-related groups" like Transcendental Meditation (TM), ISKCON (Hare Krishnas), and Divine Light Mission also became established in Britain. Their followers are mainly Western converts. 
During the 1970s and 1980s, Knott observed an apparent "diversity of these two forms of religiousness, of the Indian Hindu population, and the Hindu related groups". 3 The recent dispute over the threatened closure of ISKCON's main temple, the Bhaktivedanta Manor, however, generated large support from the Indian Hindus and brought the two folds closer together. ${ }^{4}$

The Hindu presence in the Netherlands stems from the mass migration during the mid-1970s, as in the wake of the independence of Suriname (former DutchGuiana) some 80,000 to 100,000 Surinamese Hindustanis came. The Hindus from Suriname brought with them their particular form of "Caribbean Hinduism", which has been perpetuated in the Dutch setting. Both the central position of the Brahman priest as well as the factionalism in Arya Samaj and Sanatan Dharm shapes the Hindu presence in the Netherlands. In 1991, the Arya Samaj maintained 26 regional societies and foundations and three temples. Likewise, the Sanatan Dharm was organized in three national and 40 regional societies, maintaining 16 temples. As such, Hinduism in the Netherlands has become "denominationalized" into these groupings. 5

In the shadow of Surinamese Hinduism, some 4,000 Tamil Hindus, all refugees from Sri Lanka, have found asylum in the Netherlands. In addition, quite a number of Hindu-related groups are traceable. The academic stock-taking of 1991 lists 27 groups and movements, the Hare Krishna (ISKCON) and the Sathya Sai Baba tradition being the more active and established ones. A purposely built temple, as in Britain, has not, however, been realized up to now by the about 100,000 Surinamese Hindus in the Netherlands.

In Germany, Hindu immigration started in the 1950s, mainly of skilled professionals from various Indian states. Interest in founding societies and places of worship has been, however, very low among these scattered individuals, many of them being married to a German wife.
Since the mid-1980s, due to the escalation of the civil war in Sri Lanka, some 60,000 Tamils came to Germany, among them about 45,000 Hindus. The Tamils maintain, if financially and spatially possible, amply decorated temples, some in subterrace flats, some in former industrial halls. Apart from its religious importance for the carrying out of pujas, life-cycle rituals, and festivals, these temples also function as socio-cultural meeting points. In a few places, Tamil language and dance classes have additionally been organized. Finally, such annual temple festivals as in Hamm (Northern Germany) with its public procession, attended by some 4,000 to 6,000 people, attract Tamils from all over Germany, giving a flavour of "South Indianness" to the industrial town. ${ }^{6}$

Hinduism in Germany is numerically dominated by Tamils. Estimates go to about 65,000 Hindus all in all, organized in about 100 cultural societies. The public profile and appearance of Hinduism in Germany is low and non-spectacular. Many people would not even know that some several tens of thousands Hindus reside in Germany.

In Portugal the Hindu community is made up of some 8,000 Gujarati Hindus, most of them refugees from Mozambique. Almost all have settled in the capital Lisbon, especially in the poor districts called Quinta da Holandesa and Quinta da Montanha. During their by now 20 years of residence some very few became affluent as tradesmen, doctors, or technicians; most of them, however, remained in low paid occupations. Like elsewhere, Hindus in Portugal strive to preserve their Hindu identity by way of public festivals, home rituals, and supplementary classes for the children. Temples have been established in Lisbon, Porto, and Faro. A special problem for the Hindus in Portugal, however, stems from the fact that their children grow up speaking Portuguese as their mother-tongue, making communication with Hindus in Europe and India much more difficult. ${ }^{7}$ 


\section{Hindu-Christian Dialogue in Practice} As the British Hindu "community", or rather the multitude of different communities, have the lead in Europe, most related interfaith activities within Europe take place in Britain. This is due to the numerical size of a half million Hindus as well as to the establishment of Hindu societies occurring earlier than those on the continent. No attempt will be made to list all relevant activities and organizations as observable in Britain, the Netherlands, Switzerland, or Germany. Rather, a rough classification of Hindu-Christian encounters will be given. Apparently, many of these face-to-face meetings and institutionalized events also have parallels in other diasporic settings where Hindus live, as described in this issue. Thus, a few examples taken from the European scene will be sufficient.

On a very basic level, various kinds of personal encounters between individual Christians and Hindus are observable. Often Christians, active in their own parish, have been supportive to Hindus (and other "foreign" people) who just arrived in their town or city as migrants and face all the difficulties of establishing life, getting along with the administration, and so forth. The Christian attitude to help one's neighbour provided the incentive to a wide range of supportive initiatives and activities.

Often, such individual interest and help has been transferred or led to an involvement of the local Christian parish or an interfaith group. Such institutional help again has taken on a spectrum of various activities: In Basel (Switzerland), for example, in the mid-1980s Tamil Hindus were able to have regular pujas in the library of the interreligious organization Inforel (Information about Religions). Since Tamils built their own Ganeśa temple in 1996, Inforel has arranged visits and conducts guided tours to the Sri Sithi Vinayakar Alayam temple. In my own home city, Bielefeld (Northern Germany), the Catholic students' community has put its meditation room at the temporary disposal of the Tamil refugees. Due to the absence of any other possibility, the local Brahman conducts the weekly puja in that locality, the crucified Christ hanging above a statue of Ganeśa centred on the temporary altar. Apart from such altruistic supports, to which many more examples can be added, it also needs to be noted that in some cases meetings and encounters are designed to convert Hindus to Christianity. The local Brahman from Bielefeld calls some of them "potato Christians", due to the fact that they were "converted" in connection with a lunch invitation from the Christian pastor.

On a next level of organizational initiatives, in many bigger towns and cities, especially in Britain, local "Councils of Faiths" have been established. Such "InterFaith Councils" tend to be more formally structured and attempt to maintain a balanced representation from among the principal religions in that city. Often, such councils take on the role of representing the concerns of their local religious communities to the respective authorities and other public bodies.

Finally, in a number of European countries national interfaith organizations have been established. In Britain, the 1987 set up "Inter Faith Network of the UK" links about 80 organizations active in interreligious dialogue. The Network provides information, serves as a forum for meeting and exchange, and aims to enhance mutual understanding. Likewise, the "World Conference on Religion and Peace" and the "International Association for Religious Freedom" have branches in many countries. ${ }^{8}$

Despite the honourable motives and initiatives, such organizational dialogue activities also entail the problem of appointing a representative or speaker of a sometimes quite heterogenous "community". Hinnells rightfully points out

that the Hindus/Muslims/Parsis/Sikhs who have been drawn into such dialogue have generally been the educated, the good communicators, often Westernized, perhaps rather 
liberal, members of the traditions. Their role in interfaith dialogue, especially when this has resulted in contact with significant social leaders, such as state governors or British royalty, has given these representatives a status, influence, even authority, back in the community, an authority they might not otherwise have had and sometimes despite the fact that they are not necessarily typical or traditional. ${ }^{9}$

The question of leadership and representation not only applies to the institutional and personal level, but also stirs up problems as regards doctrinal interpretations and conceptualizations.

\section{One's Hindu Faith in a Nutshell}

Interfaith encounters often involve the crossreligious comparison of specific doctrinal concepts and norms. Representatives are asked to expound on their faith and give a short but concise portrait of their beliefs. Christian partners, who most often are the initiators of meetings or symposia, implicitly assume a comparable grade of rationalization and conceptualization of doctrinal contents as found in Catholic or Protestant. theologies. Religious dimensions as visual arts, devotional commitment, and symbolic expressions are not a top priority asked and looked for, especially not from the Protestant side. Rather, questions as regards text and scripture and an essentialization as regards belief contents are sought after. Each religious tradition must have a central creed and authoritative texts, the assumption goes.

In this way interfaith activities also, among other influences, have contributed to a reconceptualization of the nostalgicly conceived "Hindu way of life". In particular in Britain and the Netherlands, to a growing extent one's Hindu way is more and more perceived as a rationalized "religion" in the modern, Christian sense. The once more or less all-encompassing religious-cultural sphere becomes compartmentalized, the sacred sphere relegated to specific places, events, times, and contents. Compared to previous experiences when the dharma of each caste to a very large extent conditioned one's place and function in society, increasingly, as Milton Singer has termed it, a "ritual neutralization" and "vicarious ritualization" of the non-sacred sphere takes place. ${ }^{10}$ As Knott observed with regard to British Hindus, the perception of being a minority religion in a simultaneously secular and multi-faith society

affected the way Hindus think about themselves and their faith. Some are beginning to think of Hinduism as many people do of Christianity, something to be remembered during large festivals and at births, marriages and deaths. Others have retained a more traditional view of Hinduism as "a way of life". .11

Similarly, Jackson and Nesbitt concluded with regard to Hindu-British children:

"Hinduism" becomes more of a chosen pursuit, a rich subject for organized children's classes, camps and festivals, rather than a total way of life. [...] It seems likely that "Hinduism", for the children we studied, is becoming a more discrete area of experience, one which can be deliberately avoided or which can be visited, for cultural enrichment or fellowship with coreligionists, rather than being a total way of life. ${ }^{12}$

These processes of compartmentalization to a lasting extent have affected the conceptional sphere, as van Dijk has pointed out to Surinamese Hindus in the Netherlands. Van Dijk calls it a "process of becoming a religion" ("Religionisierung"), in which the former "ethno-cultural religion changes to a confession of faith": Hinduism as a "lived and experienced religion develops to a believed, considered and systematized religion". ${ }^{13}$ A clear sign of such reconceptualizations are the creation of "Hindu catechisms" and of the "nine articles of Hindu faiths" and the emphasized importance of texts. ${ }^{14}$

Such reconceptualizations have not, 
however, taken place in Europe only, as examples from India, the Caribbean and elsewhere demonstrate. In certain contexts such processes have emerged without Western and Christian influence, as Singer already has pointed out with regard to India. ${ }^{15}$ In the diasporic context, however, such processes of compartmentalization may be instigated or initiated by interfaith encounters. This may especially be the case when such activities are favoured by the dominant dialogue partner, who in the European context more often than not comes from the Christian side. This point is not a criticism, but rather aims to analytically point to some implications of interfaith dialogue for the minority, diasporic religion.

\section{Notes}

1. For overviews see Richard Burghart (ed.), Hinduism in Great Britain, (London, New York: Tavistock, 1987) and Kim Knott, "Bound to Change? The Religions of South Asians in Britain", in: Steven Vertovec (ed.), Aspects of South Asian Diaspora, (Vol. 2, Delhi: Oxford University Press, 1991.

2. As regards the second generation, see Robert Jackson, Eleanor Nesbitt, Hindu Children in Britain, (Stoke-on-Trent: Trentham 1993). For the statistics see Knott, "Bound to Change?", p. 91 and Paul Weller, Religions in the UK. A Multi-Faith Directory, (2nd ed. Derby: University of Derby, 1997), p. 28.

3. Kim Knott, Hinduism in Leeds, (Leeds: Community Religions Projects 1986, repr. 1994), p. 235.

4. Malory Nye, "Hare Krishna and Sanatan Dharm in Britain: The Campaign for Bhaktivedanta Manor", Journal of Contemporary Religion, 11, 1 (1996): pp. 37-56. There is a wealth of substantial studies on Hindus and Hindu traditions in Britain, see the on-line bibliography by Martin Baumann, "Hindus and Hindu Traditions in Europe", (http://www.rewiuni-hannover.de/for2.htm, January 1998).

5. Alphons van Dijk, "Hinduismus in Suriname und den Niederlanden", Zeitschrift für Missionswissenschaft und Religionswissenschaft, 80, 3 (1996): pp. 179-195. For the statistics see the stock-taking by Jan Peter Schouten, "Nieuwe wegwijzer in hindoeïstisch Nederland", Religieuze bewegingen in Nederland, 23 (1991): pp. 49-97.

6. See Martin Baumann, "Feste tamilischer Hindus in Deutschland", in: Remid (ed.), Religionen feiern, (Marburg: Diagonal, 1997), pp. 198-200. Up to now only a rather impressionistic study on Hindus in Germany exists, see Elisabeth Dessai, Hindus in Deutschland, (Moers: Aragon, 1994), for the Hindu Tamils see pp. 185-204. In addition, some 5,000 Hindus from Afghanistan have been granted asylum, see Dessai, Hindus, pp. 205-14.

7. For Portugal and further Hindu communities in Europe, see Martin Baumann, "Sustaining one's 'Little India': The Hindu Diasporas in Europe", in: Gerrie ter Haar (ed.), Strangers and Sojourners: Religious Communities in the Diaspora, (Leuven: Uitgeverij Peeters 1998, in press).

8. For Britain see the overview by Weller, Religions in the UK, pp. 67-80. For topics and issues of Christian-Hindu dialogue see most recently Andreas Bsteh (ed.), Der Hinduismus als Anfrage an christliche Theologie und Philosophie, (Moedling: St. Gabriel, 1997).

9. John Hinnells, "Comparative Reflections on South Asian Religion in International Migration", in: John Hinnells (ed.), A New Handbook of Living Religions, (Oxford: Blackwell, 1997), pp. 819-47, quote p. 835.

10. Milton Singer, When a Great Tradition Modernizes, (London: Pall Mall Press, 1972), pp. 325-35.

11. Knott, Hinduism, p. 46.

12. Jackson, Nesbitt, Hindu Children, p. 179.

13. Van Dijk, "Hinduismus", quotes p. 193, 191, 193. Translations by M.Baumann.

14. See the Leeds temple circular "Hinduism Sanatana Dharma", reproduced in Knott, Hinduism, pp. 295-6 and "Our Prayer" and "Neun Glaubenssätze des Hinduismus", in: VHP (ed.), 5th European Hindu Conference, (Osnabrück: Fromm, 1992), p. 73, p. 163.

15. Singer, Great Tradition, 1972, p. 323. 